\title{
Skema Transfer Pricing Pada Perusahaan Pertambangan dan Faktor-Faktor yang Terlibat
}

\author{
Suparno ${ }^{1}$ \\ Fakultas Ekonomi dan Bisnis \\ Universitas Airlangga, indonesia. \\ Email: suparnose@yahoo.com
}

\author{
Tjiptohadi Sawarjuwono ${ }^{2}$ \\ Fakultas Ekonomi dan Bisnis \\ Universitas Airlangga, Indonesia.
}

\begin{abstract}
ABSTRAK
Tujuan penelitian ini adalah untuk menganalisis dan mendeskripsikan skema penghindaran pajak melalui transfer pricing yang umumnya dilakukan oleh perusahaan pertambangan, menganalisis dan menemukan faktor yang mempengaruhi keputusan transfer pricing oleh perusahaan pertambangan. Penelitian ini berjenis deskriptif menggunakan data kualitatif yang diperoleh dari studi literatur dari sumber internet. Analisis data menggunakan teknik kualitatif yang terdiri dari tiga tahapan, yaitu telaah data, reduksi data, dan penarikan kesimpulan. Hasil penelitian menunjukkan skema transfer pricing yang dilakukan perusahaan pertambangan secara umum dapat dibagi menjadi dua, yaitu dengan melakukan pengalihan kuasa pertambangan pada perusahaan lain yang memiliki hubungan istimewa dan melakukan transaksi dengan perusahaan yang memiliki hubungan istimewa, dengan harga yang disepakati di bawah rata-rata harga pasar. Hasil penelitian menunjukkan keputusan transfer pricing perusahaan tambang dipengaruhi oleh sembilan faktor yang terdiri dari karakteristik eksekutif, leverage, skala perusahaan sebagai perusahaan multinasional, pengungkapan tanggung jawab sosial, capital intensity, kepemilikan institusional, komite audit, kualitas audit, dan transparansi informasi.
\end{abstract}

Kata Kunci: Transfer Pricing, Penghindaran Pajak, Perusahaan Pertambangan.

\section{Transfer Pricing Schemes in Mining Companies and Factors Involved}

\section{ABSTRACT}

The purposes of this study are to analyze and describe the tax avoidance schemes through transfer pricing and the factors that influence the decision on transfer pricing by mining companies. Data analysis uses qualitative techniques with qualitative data obtained from literature studies from internet sources. The results of the study shows that the transfer pricing schemes carried out by mining companies in general can be divided into two, namely by transferring mining rights to other companies that have special relationships and conducting transactions with companies that have special relationships, with prices agreed to be below the average market price. The results of the study also indicate that the mining company's decision to transfer pricing is influenced by nine factors, namely executive characteristics, leverage, scale of the company as a multinational company, disclosure of social responsibility, capital intensity, institutional ownership, audit committee, audit quality, and information transparency.

Keywords: $\quad$ Transfer Pricing, Tax Avoidance, Mining Companies.

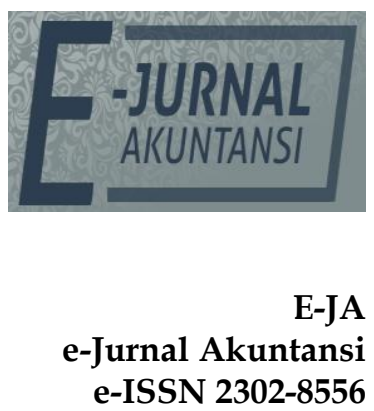

Vol. 29 No. 2

Denpasar, November 2019

Hal. 765-778

Artikel masuk: 18 Oktober 2019

Tanggal diterima: 23 November 2019 


\section{PENDAHULUAN}

Pajak merupakan sebuah kewajiban bagi wajib pajak, baik yang bersifat perseorangan maupun korporasi, yang harus ditunaikan kepada negara sesuai dengan peraturan perpajakan yang berlaku. Keberadaan pajak memang dianggap sebagai beban oleh wajib pajak karena dapat mengurangi pendapatan atau keuntungan yang diterimanya (Rachdianti, 2016). Meskipun negara tidak memberikan kontraprestasi secara langsung kepada wajib pajak atas pajak yang dibayar, namun sebenarnya pajak yang diterima negara dipergunakan untuk kepentingan wajib pajak, baik dalam bentuk penyelenggaraan negara maupun dalam bentuk pembangunan sarana dan prasarana publik (Hidayat, 2018). Setelah pemerintah menetapkan pajak sebagai target penerimaan negara yang utama pada APBN 1998, maka besar pajak yang diterima negara terus mengalami peningkatan secara signifikan dari tahun ke tahun (Budileksmana, 2018). Seiring dengan semakin besarnya kebutuhan dana negara untuk melakukan pembangunan dan penyelenggaraan negara, maka target penerimaan pajak juga terus ditingkatkan. Data peningkatan target penerimaan pajak negara dapat dilihat pada tabel 1.

\section{Tabel 1. Pertumbuhan Target Penerimaan Pajak}

\begin{tabular}{ccc}
\hline Tahun & Target Penerimaan Pajak (Triliun) & $\begin{array}{c}\text { Pertumbuhan } \\
\text { Perpajakan }(\%)\end{array}$ \\
\hline 2015 & $1.240,4$ & 8,2 \\
2016 & $1.285,0$ & 3,6 \\
2017 & $1.472,7$ & 14,6 \\
2018 & $1.618,1$ & 10 \\
2019 & $1.786,4$ & 10,4 \\
\hline
\end{tabular}

Sumber: Kementrian Keuangan Republik Indonesia, 2019

Salah satu upaya pemerintah untuk dapat memenuhi target penerimaan pajak yang terus meningkat dari tahun ke tahun adalah dengan menekan terjadinya penghindaran pajak oleh wajib pajak. Menurut Putra, Syah, \& Sriwedari (2018), penghindaran pajak adalah upaya yang dilakukan oleh wajib pajak untuk meminimalisir beban pajak yang harus dibayarkan kepada negara dengan memanfaatkan peluang yang ada dalam peraturan perpajakan sebuah negara. Meskipun tidak menyalahi peraturan pajak, namun tindakan tersebut pada dasarnya tidak sesuai dengan jiwa undang-undang perpajakan serta dapat membuat penerimaan pajak negara menjadi tidak optimal. Di antara beberapa sektor usaha unggulan yang ada, sektor pertambangan merupakan sektor yang terindikasi sering melakukan penghindaran pajak dengan metode transfer pricing (Busthomi, 2016). Transfer pricing dapat juga dimaknai sebagai kebijakan harga yang digunakan dalam transaksi yang terjadi antar perusahaan yang memiliki hubungan istimewa (Barker, Asare, \& Brickman, 2017). Melalui transfer pricing, maka perusahaan pertambangan dapat menghindari besar pajak yang seharusnya dibayarkan ke negara karena pendapatannya yang rendah sebagai hasil nilai transaksi yang murah dengan perusahaan afiliasi. Mengingat sektor pertambangan adalah salah satu sektor unggulan yang diharapkan dapat memberikan kontribusi pajak yang semakin besar, maka praktik penghindaran pajak dengan metode transfer pricing ini sangat merugikan negara. 
Menurut Peneliti Ekonomi Lembaga Ilmu Pengetahuan Indonesia Pusat Penelitian Ekonomi (P2E-LIPI), praktik transfer pricing menimbulkan ketidakadilan terhadap wajib pajak, sehingga perlu untuk ditindaklanjuti, Menurut Kepala Bidang Pemeriksaan Penyidikan dan Penagihan Pajak, menjelaskan bahwa transfer pricing sebagai penurunan beban pajak bukan merupakan hal yang tabu sehingga dapat dilakukan oleh wajib namun tetap memperhatikan prinsip kewajaran. Dalam Undang-Undang Ketentuan Umum dan Tata Cara Perpajakan juga diketahui bahwa di satu sisi praktek transfer pricing merupakan salah satu bentuk tax planning yang tidak melanggar ketentuan perpajakan, namun disisi lain praktik transfer pricing dikategorikan sebagai tindak pidana perpajakan yang ditunjukkan dalam Bab VIII tentang Ketentuan Pidana.

Beberapa hasil penelitian terdahulu juga menerangkan bahwa fungsi transfer pricing yang dilakukan oleh perusahaan bertujuan untuk mengurangi beban pajak perusahaan (Safitri \& Aulia, 2017). Lebih lanjut menurut Safitri \& Aulia (2017), untuk dapat mengurangi penyalahgunaan praktik transfer pricing yang dilakukan perusahaan, behavioral accounting berperan penting untuk mengubah perspeksi mengenai praktik transfer pricing. Hal ini dikarenakan upaya melalui pelatihan terhadap sumber daya yang mengatur peraturan perpajakan tidak efektif menekan transfer pricing yang dilakukan perusahaan dengan tujuan melakukan penghindaran pajak (Waris, 2013).

Berdasarkan fenomena mengenai transfer pricing yang dilakukan oleh perusahaan pertambangan di Indonesia, maka perlu dilakukan kajian untuk mengetahui skema transfer pricing oleh perusahaan pertambangan serta faktorfaktor yang mempengaruhi keputusan transfer pricing tersebut. Sesuai dengan latar belakang yang telah dipaparkan di atas, maka penelitian ini mengangkat dua rumusan masalah, yaitu bagaimana skema penghindaran pajak melalui transfer pricing yang umumnya dilakukan oleh perusahaan pertambangan dan faktor-faktor apa sajakah yang mempengaruhi keputusan transfer pricing oleh perusahaan pertambangan Dengan mengacu pada rumusan masalah tersebut, maka penelitian ini bertujuan untuk menganalisis dan mendeskripsikan skema penghindaran pajak melalui transfer pricing yang umumnya dilakukan oleh perusahaan pertambangan dan menganalisis serta menemukan faktor-faktor yang mempengaruhi keputusan transfer pricing oleh perusahaan pertambangan. Nilai tambah dari penelitian ini adalah penggunaan theory of planned behavior untuk mendukung menjelaskan faktor yang mendukung perusahaan pertambangan melakukan transfer pricing.

Theory of planned behavior merupakan kerangka konseptual yang digunakan untuk meneliti perilaku individu dimana melalui theory of planned behavior memungkinkan dapat diketahui faktor yang mempengaruhi keputusan individu dalam berperilaku sehingga dapat dikatakan individu dalam berperilaku didasarkan atas pertimbangan-pertimbangan rasional. Theory of planned behavior menjelaskan bahwa perilaku seseorang ditentukan oleh niat berperilaku (Lindblom \& Lindblom, 2018).

Burhanudin (2012) menjelaskan bahwa theory of planned behavior menjelaskan perilaku konsumen yang kompleks yang membutuhkan kontrol keperilakuan atau kemampuan untuk berperilaku. Setiap tindakan individu manusia selalu 
didasarkan atas tindakan subjektif yang merujuk pada makna motif yang sebelumnya mengalami proses intersubjektivitas berupa hubungan interaksi antarpersonal yang bersifat unik. Tindakan setiap manusia adalah tindakan pilihan rasional (rationale choice). Tindakan pilihan rasional tersebut senantiasa terkait dengan memahami motif dan arti dari tindakan masing-masing individu itu sendiri.

Ajzen (2005) menyatakan theory of planned behavior menerangkan bahwa teori tindakan yang direncanakan sebagai tindakan manusia dibimbing oleh tiga macam faktor, yaitu attitude, subjective norms, dan perceived behavior control. Ajzen (2005) menjelaskan bahwa attitude yang dimaksud adalah perasaan memihak (favorableness) dan perasaan tidak memihak (unfavorableness) terhadap sebuah obyek yang akan disikapi. Dalam hal ini, sikap untuk melakukan transfer pricing dapat terbentuk apabila wajib pajak memiliki keyakinan dan evaluasi yang memihak atau keyakinan yang positif terhadap manfaat dari transfer pricing. Sebagaimana diungkapkan pula pada penelitian yang dilakukan oleh Permatasari \& Laksito (2013) bahwa ketika sistem perpajakan yang berlaku dirasa semakin tidak adil, maka tingkat kepatuhan wajib pajak akan semakin menurun.

Pada faktor berikutnya, yaitu subjective norms, menurut Ajzen (2005) dijelaskan sebagai adanya tekanan sosial yang dipersepsikan untuk melaksanakan perilaku. Dalam hal ini, yang dimaksud dengan tekanan sosial dapat dijelaskan sebagai adanya referensi dari pihak yang dipercaya oleh wajib pajak yang dapat mendorong untuk melakukan transfer pricing. Dicontohkan pada salah satu penelitian yang dilakukan oleh Wallschutzky (1985) yang menjelaskan bahwa salah satu pihak yang dipercaya oleh wajib pajak, adalah penasehat atau konsultan pajak. Dalam hasil penelitian dijelaskan bahwa bentuk pernyataan atau referensi yang ditawarkan oleh konsultan pajak akan memberikan pengaruh terhadap niat berperilaku wajib pajak. Pada perceived behavior control, Ajzen (2005)menjelaskan bahwa kontrol perilaku yang dipersepsikan menggambarkan mengenai persepsi wajib pajak untuk menilai praktik transfer pricing akan mudah untuk dilakukan atau tidak berdasarkan pada pengalaman di masa lalu. Spicer \& Hero (1985) mencontohkan bahwa bagi wajib pajak yang pernah diperiksa atau diaudit akan dapat menilai dimasa yang akan datang laporan keuangan akan diperiksa lebih ketat atau tidak sehingga hal ini menjadi pertimbangan wajib pajak untuk melakukan praktik transfer pricing.

Praktik transfer pricing yang dilakukan oleh perusahaan juga memiliki hubungan dengan arm's length principle. Hal ini dijelaskan oleh Pohan (2018), bahwa transaksi afiliasi yang dilakukan oleh pihak independen sebagai wajib pajak dan pihak afiliasinya dapat digunakan sebagai alat untuk melakukan penghindaran pajak. Oleh karena itu, wajib bagi wajib pajak dalam melakukan transaksi dengan pihak afiliasi untuk menerapkan prinsip arm's length.

\section{METODE PENELITIAN}

Penelitian ini berjenis deskriptif, yaitu penelitian yang memberikan penjelasan berdasarkan data penelitian berupa rangkaian bahasa dalam bentuk teks. Data tersebut diinterpretasikan dengan tepat dan sistematis untuk bisa mendapatkan kepahaman yang mendalam mengenai topik yang diteliti. Pelaksanaan penelitian 
deskriptif memerlukan pemikiran yang terbuka, wawasan yang luas dan sensitifitas tinggi dalam menganalisa topik penelitian dan menginterpretasikan data yang didapatkan melalui deskripsi dalam bentuk-bentuk penjelasan yang tepat, kritis dan relevan (Wibowo, 2011). Data penelitian ini berupa data sekunder, yaitu data yang diperoleh dengan cara studi literatur dengan mengumpulkan informasi yang berkaitan dengan topik penelitian yang dibahas dari sumber internet (Silalahi, 2018). Data yang digunakan adalah data yang berkaitan dengan perusahaan pertambangan di Indonesia beserta aktivitas transfer pricing yang dilakukan. Data yang telah dikumpulkan selanjutnya di analisis menggunakan teknik kualitatif dengan tahapan analisis terdiri dari telaah data, reduksi data, dan penarikan kesimpulan (Moleong, 2017).

\section{HASIL DAN PEMBAHASAN}

Indonesia dikenal sebagai salah satu negara di dunia yang kaya atas bahan tambang. Hal ini disebabkan karena letak geografis Indonesia yang berada pada daerah "ring of fire", sehingga di dalam tanah Indonesia terkandung banyak endapan mineral, misalnya timah, batubara, nikel, emas, dan tembaga, maupun sumber daya alam lain seperti minyak dan gas bumi (Direktorat Sumber Daya Energi Mineral dan Pertambangan, 2019). Dengan adanya kekayaan sumber daya alam ini, maka prospek dari usaha tambang di Indonesia sangatlah besar. Usaha pertambangan adalah suatu usaha yang kegiatan utamanya adalah mengambil bahan tambang berharga dan dapat menghasilkan nilai ekonomis tinggi, baik dari dalam tanah maupun dari atas permukaan tanah. Usaha pertambangan umumnya dilakukan dalam 4 aktivitas inti, yaitu prospeksi, eksplorasi, eksploitasi, dan pengolahan. Sesuai dengan laporan Badan Pusat Statistik tentang Produk Domestik Bruto (PDB) Indonesia Triwulanan, usaha pertambangan dibagi menjadi 4 subkategori, yaitu pertambangan minyak dan gas bumi (migas), pertambangan batubara dan ignit, pertambangan bijih logam, dan pertambangan lainnya (Badan Pusat Statistik, 2018).

Dalam laporan tersebut, BPS juga menyatakan bahwa sektor pertambangan adalah sektor dengan rata-rata kontribusi terendah terhadap PDB pada periode 2014-2017 dibandingkan sektor pertanian, industri, dan perdagangan. Data tersebut dapat dilihat pada tabel 2 dan grafik .

Tabel 2. Kontribusi Rata-Rata Sektoral terhadap PDB 2014-2017

\begin{tabular}{ccc}
\hline No & Sektor & Kontribusi terhadap PDB \\
\hline 1 & Industri & $21,31 \%$ \\
2 & Pertanian & $13,41 \%$ \\
3 & Perdagangan & $13,37 \%$ \\
4 & Pertambangan & $11,06 \%$ \\
5 & Lainnya & $40,85 \%$ \\
\hline
\end{tabular}

Sumber: Badan Pusat Statistik, 2018

Kontribusi sektor pertambangan terhadap penerimaan pajak negara pada tahun 2018 berada pada peringkat 5 dari 6 sektor usaha utama. Data ini dapat dilihat pada tabel 3 dan gambar 1 . 
Tabel 3. Kontribusi Sektoral terhadap Penerimaan Pajak Negara 2018

\begin{tabular}{cccc}
\hline No & Sektor & \multicolumn{2}{c}{ Kontribusi terhadap Penerimaan Pajak } \\
\hline 1 & Industri Pengolahan & $280,68 \mathrm{~T}$ & $29,6 \%$ \\
2 & Perdagangan & $186,96 \mathrm{~T}$ & $19,8 \%$ \\
3 & Jasa Keuangan dan Asuransi & $126,72 \mathrm{~T}$ & $13,4 \%$ \\
4 & Konstruksi dan Real Estate & $63,04 \mathrm{~T}$ & $6,7 \%$ \\
5 & Pertambangan & $59,21 \mathrm{~T}$ & $6,3 \%$ \\
6 & Pertanian & $17,06 \mathrm{~T}$ & $1,8 \%$ \\
\hline
\end{tabular}

Sumber: Kementrian Keuangan Republik Indonesia, 2018

Data pada Gambar 1. menunjukkan bahwa sektor pertambangan memang termasuk sektor unggulan yang berkontribusi besar terhadap PDB dan penerimaan pajak negara. Namun demikian, kontribusi tersebut masih tergolong rendah jika dibandingkan dengan kontribusi sektor unggulan lainnya. Hal ini bertolak belakang dengan besarnya potensi sektor pertambangan Indonesia, sehingga upaya untuk mengoptimalkan kontribusi sektor tersebut masih sangat diperlukan.

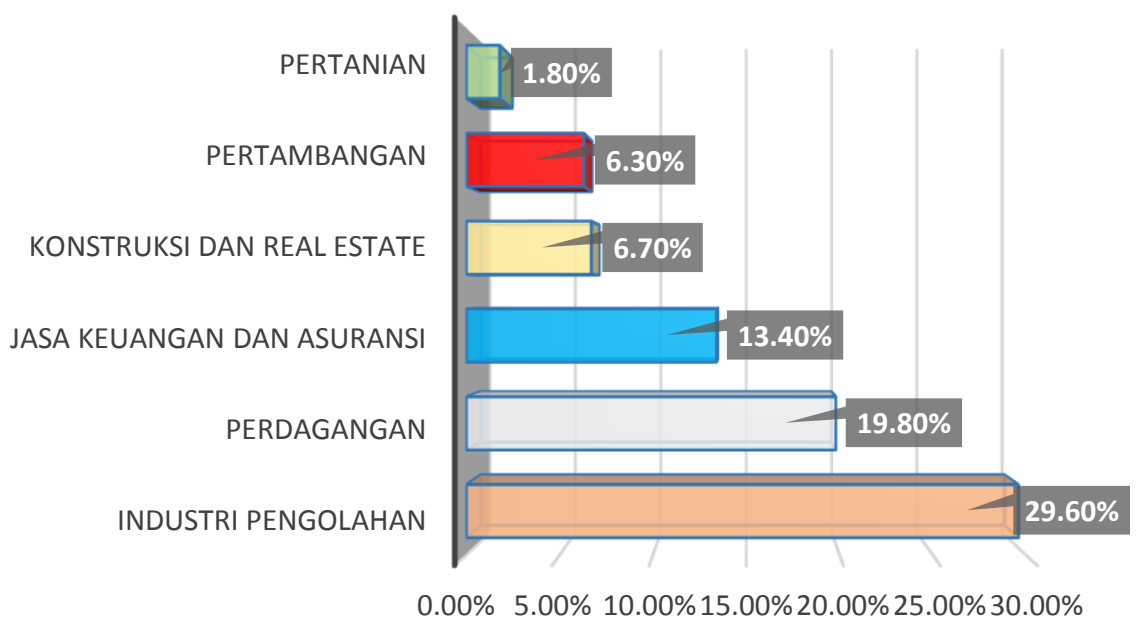

Gambar 1. Kontribusi Sektoral terhadap Penerimaan Pajak Negara 2018

Sumber: Kementrian Keuangan Republik Indonesia, 2018

Besarnya potensi pada sektor pertambangan dapat menimbulkan peluang bagi perusahaan untuk melakukan penghindaran pajak guna mengoptimalkan laba perusahaan. Oleh karena itu pemerintah menetapkan kebijakan perundangundangan untuk mencegah praktik penghindaran pajak untuk dapat mengoptimalkan penerimaan pajak negara. Salah satu praktik penghindaran pajak yang menjadi prioritas utama untuk dicegah oleh pemerintah adalah transfer pricing. Melalui Pasal 18 ayat (3) UU PPh, pemerintah memberikan kewenangan kepada dirjen pajak untuk melakukan perjanjian dengan pihak otoritas pajak negara lain untuk menentukan harga transaksi antara pihak-pihak yang memiliki hubungan istimewa. Dengan adanya kebijakan tersebut, maka pemerintah memiliki kewenangan untuk mengetahui dan menentukan harga dalam transaksi antar perusahaan yang memiliki hubungan istimewa, sehingga tidak terjadi praktik transfer pricing yang disengaja untuk mengurangi beban pajak perusahaan, atau yang disebut dengan abuse of transfer pricing. Pasal 18 ayat (3) UU PPh mewakili penerapan prinsip arm's length di Indonesia yang bertujuan 
untuk mengatur apabila kondisi dalam transaksi yang dilakukan antara pihak yang mempunyai hubungan istimewa (afiliasi) sebanding dengan kondisi dalam transaksi yang dilakukan antara pihak yang tidak memiliki hubungan istimewa sebagai pembanding (Pohan, 2018).

Dalam praktiknya, keberadaan peraturan perundang-undangan yang melarang transfer pricing masih belum dapat secara optimal menekan terjadinya praktik penghindaran pajak tersebut. Dalam konteks perusahaan pertambangan, hal ini terlihat pada banyaknya indikasi terjadinya transfer pricing yang diketahui oleh pemerintah, misalnya pada kasus dugaan penghindaran pajak oleh perusahaan tambang batubara PT Multi Sarana Avindo (MSA). Dugaan terjadinya transfer pricing oleh PT MSA didasarkan pada kecurigaan Direktorat Jenderal Pajak (DJP) atas tidak seimbangnya pajak yang dibayarkan dengan besarnya produksi tambang yang dimiliki oleh PT MSA. Selain itu, PT MSA juga melalukan pemindahan kuasa pertambangan sehingga menurunkan beban pajak yang harus dibayarkan. Atas dasar tersebut, selanjutnya DJP menggugat PT MSA sebesar 7,7 miliar pada tahun 2007, 2009, dan 2010 atas dugaan penghindaran pajak yang pada akhirnya dimenangkan oleh PT MSA karena pengadilan tidak dapat membuktikan adanya pelanggaran peraturan perundang-undangan pajak oleh PT MSA (Yuliawati, 2019).

Kasus dugaan transfer pricing kedua dilakukan oleh perusahaan pertambangan batubara yaitu PT. Adaro Indonesia pada tahun 2008. Skema transfer pricing yang diduga dilakukan oleh PT Adaro Indonesia adalah dengan cara menjual batubara dengan harga rendah di bawah harga pasar kepada perusahaan Singapura Coaltrade Service International Pte, Ltd yang merupakan perusahaan afiliasi dari PT Adaro Indonesia. Selanjutnya Coaltrade Service International Pte, Ltd menjual batubara tersebut dengan harga pasar. Skema ini menyebabkan PT Adaro Indonesia memperoleh keuntungan yang rendah, sehingga besar royalti dan pajak yang harus dibayarkan ke negara juga rendah. Hal yang mencurigakan adalah keuntungan yang diperoleh Coaltrade Service International Pte, Ltd sebagai trader jauh lebih besar daripada PT Adaro Indonesia yang merupakan perusahaan tambang. Berdasarkan hal ini, maka diduga terdapat upaya penghindaran pajak oleh PT Adaro Indonesia dengan metode transfer pricing yang melibatkan perusahaan afiliasinya, yaitu Coaltrade Service International Pte, Ltd yang berada di Singapura. Kasus ini berakhir dengan keputusan Kejaksaan Agung yang menyatakan tidak adanya cukup bukti sehingga penyelidikan transfer pricing oleh PT Adaro Indonesia harus dihentikan (Biro Analisa Anggaran dan Pelaksanaan APBN, 2014).

Dua kasus dugaan transfer pricing di atas pada akhirnya memang tidak dapat dibuktikan sebagai pelanggaran terhadap regulasi perpajakan Indonesia. Namun indikasi yang ditemukan oleh DJP dapat menggambarkan skema transfer pricing yang umumnya digunakan oleh perusahaan pertambangan, yang pertama adalah melakukan pengalihan kuasa pertambangan kepada perusahaan lain yang memiliki hubungan istimewa, sehingga memungkinkan terjadinya transfer pricing yang pada akhirnya dapat menurunkan besar pajak yang harus dibayarkan kepada negara. Yang kedua adalah dengan melakukan transaksi dengan perusahaan yang memiliki hubungan istimewa, seperti antara perusahaan induk dan anak cabang perusahaan yang berada di luar negeri, 
dengan harga yang besarnya disepakati di bawah rata-rata harga pasar. Praktik ini akan menyebabkan pajak perusahaan yang berada dalam negeri menjadi lebih sedikit karena harga jual yang rendah. Selanjutnya, perusahaan afiliasi yang membeli produk dengan harga murah tersebut menjual ke pasar sesuai dengan harga rata-rata yang berlaku. Lokasi perusahaan afiliasi yang berada di luar negeri dengan pajak yang lebih rendah daripada di Indonesia akan menyebabkan beban pajak perusahaan secara keseluruhan menjadi lebih rendah dengan tingkat keuntungan yang sama.

Skema transfer pricing perusahaan pertambangan di atas sesuai dengan konsep dasar transfer pricing yang dijelaskan oleh Putri (2017), bahwa penghindaran harga dengan metode transfer pricing dapat dilakukan dengan memanipulasi harga jual atau harga beli, atau dengan melakukan penjualan atau pembelian aset perusahaan dengan nilai yang lebih rendah dari nilai pasar. Meskipun skema yang digunakan dapat beragam, namun inti dari upaya tersebut adalah membuat beban pajak perusahaan secara keseluruhan menjadi lebih sedikit. Praktik ini memang secara administratif tidak melanggar regulasi perpajakan, namun secara moril tentu berlawanan dengan tujuan diterapkannya arm's length principle melalui berbagai kebijakan pemerintah mengenai perpajakan karena hasil akhirnya membuat negara tidak dapat menerima pajak secara optimal.

Skema transfer pricing oleh perusahaan pertambangan dilakukan dengan tujuan utama untuk menekan besar beban pajak yang menjadi kewajiban perusahaan kepada negara. Meskipun menurut Putra, Syah, \& Sriwedari (2018), terdapat juga tujuan-tujuan lain dari dilakukannya transfer pricing, namun dampak yang paling signifikan serta yang menjadi tujuan akhir adalah untuk membuat perusahaan tidak mengeluarkan beban pajak yang besar. Selain didasarkan pada perspektif perusahaan sebagai wajib pajak yang menilai pajak sebagai sebuah beban yang dapat mengurangi besar keuntungan yang diperoleh, keputusan yang diambil oleh perusahaan pertambangan untuk melakukan transfer pricing juga dapat dipengaruhi oleh beragam faktor lain. Menurut penelitian yang dilakukan oleh (Dewi, 2016) terhadap perusahaan pertambangan yang terdaftar di BEI periode 2011-2013, dapat diketahui bahwa keputusan untuk melakukan penghindaran pajak oleh perusahaan pertambangan dipengaruhi oleh karakteristik eksekutif, leverage, skala perusahaan sebagai perusahaan multinasional, dan pengungkapan tanggung jawab sosial. Faktor karakteristik eksekutif menjelaskan sifat dari jajaran manajemen puncak perusahaan terkait dengan kecenderungan untuk mengambil risiko atau menghindari risiko. Jika manajemen puncak cenderung untuk mengambil risiko, maka keputusan yang diambil lebih cenderung ke arah tidak melakukan transfer pricing. Sebaliknya, Dewi (2016) menemukan bahwa karakteristik eksekutif pada perusahaan pertambangan yang diteliti lebih cenderung ke arah penghindaran risiko. Dalam hal ini, yang dimaksud risiko adalah besarnya pajak yang harus dibayarkan perusahaan, sehingga dengan karakteristik eksekutif yang cenderung menghindari risiko akan mempengaruhi keputusan untuk melakukan transfer pricing. Hal ini juga dijelaskan oleh Hongren \& Foster (2008) bahwa terdapat tekanan dari perusahaan induk untuk dapat melakukan efisiensi secara total, 
termasuk pada beban pajak perusahaan dengan memindahkan penghasilan perusahaan anggota ke perusahaan anggota lain yang terdapat pada negara dengan beban pajak yang paling rendah. Hal ini termasuk dalam subjective norms dalam theory of planned behavior yang menjelaskan mengenai adanya tekanan yang dialami oleh perusahaan anggota dari perusahaan induk untuk dapat mengoptimalisasi laba perusahaan, yang salah satunya melalui efisiensi pada beban pajak perusahaan.

Faktor kedua yang menurut Dewi (2016) memberikan pengaruh signifikan terhadap keputusan perusahaan pertambangan untuk melakukan transfer pricing adalah leverage, yaitu total hutang perusahaan dibagi total aset. Artinya, semakin besar hutang perusahaan, maka semakin besar kecenderungan perusahaan melakukan transfer pricing. Perusahaan berupaya menekan seminimal mungkin besar pajak yang harus dibayar karena ada kemungkinan perusahaan tidak memiliki cukup sumber daya finansial untuk menutup hutang sekaligus membayar pajak yang besar. Faktor ketiga yang juga memberikan pengaruh signifikan terhadap keputusan melakukan transfer pricing adalah skala perusahaan sebagai perusahaan multinasional. Hal ini didasarkan pada salah satu konsep transfer pricing yang memanfaatkan perbedaan tarif pajak antar negara untuk memperoleh beban pajak seminimal mungkin (Putra, Syah, \& Sriwedari, 2018). Dengan demikian, perusahaan yang telah berskala internasional cenderung melakukan transfer pricing daripada perusahaan yang masih belum berskala internasional karena adanya faktor perbedaan tarif pajak antar negara yang dapat menekan besar pajak yang harus dibayarkan kepada negara. Menurut Ajzen (2005) kondisi demikian sesuai dengan faktor attitude dalam theory of planned behavior, yang menjelaskan bahwa perusahaan akan melakukan transfer pricing ketika perusahaan memiliki keyakinan bahwa transfer pricing yang dilakukan memiliki manfaat bagi perusahaan, yaitu menekan biaya pajak perusahaan.

Faktor keempat adalah pengungkapan tanggung jawab sosial yang juga ditemukan oleh Dewi (2016), memiliki pengaruh signifikan terhadap keputusan perusahaan pertambangan melakukan transfer pricing. Pengungkapan tanggung jawab sosial berkaitan dengan pelaporan perusahaan terhadap seluruh stakeholder dan masyarakat mengenai aktivitas perusahaan yang memiliki dampak sosial. Semakin perusahaan aktif melakukan pengungkapan tanggung jawab sosial, maka perusahaan akan semakin agresif melakukan tindakan transfer pricing. Hal ini disebabkan karena adanya biaya yang harus dikeluarkan perusahaan untuk melakukan berbagai aktivitas yang berkaitan dengan tanggung jawab sosial beserta pelaporannya, sehingga perusahaan berupaya menekan beban pajak yang menjadi tanggung jawabnya. Dalam theory of planned behavior juga dijelaskan bahwa pengungkapan tanggung jawab sosial dapat dijelaskan sebagai faktor subjective norms, yaitu sebuah bentuk tekanan sosial yang dipersepsikan oleh perusahaan untuk melaksanakan transfer pricing atau tidak (Ajzen, 2005). Semakin tinggi tekanan sosial yang dialami perusahaan, yang berarti perusahaan dituntut untuk mengungkapkan tanggung jawab sosial, maka akan menutup peluang perusahaan untuk melakukan praktik transfer pricing. 
Penelitian oleh Astrianti \& Triyanto (2018) menemukan faktor lain yang juga mempengaruhi keputusan perusahaan pertambangan untuk melakukan transfer pricing, yaitu capital intensity. Pengertian dari capital intensity adalah tingkat investasi perusahaan terhadap aset tetap. Semakin tinggi capital intensity, berarti semakin besar aset tetap perusahaan. Astrianti \& Triyanto (2018) menemukan bahwa capital intensity berpengaruh signifikan terhadap keputusan melakukan transfer pricing, yang berarti semakin besar aset tetap yang dimiliki oleh perusahaan pertambangan akan mendorong semakin besar kecenderungan perusahaan melakukan transfer pricing. Meskipun terdapat depresiasi nilai aset yang dapat menurunkan beban pajak perusahaan, namun kemungkinan nilai depresiasi tersebut masih jauh di bawah pengurangan beban pajak yang harus dibayar kepada negara jika perusahaan melakukan transfer pricing.

Faktor-faktor lain yang dapat mempengaruhi transfer pricing menurut penelitian Wijayanti, Masitoh, Mulyani (2018) adalah kepemilikan institusional, komite audit, dan kualitas audit. Kepemilikan institusional merujuk pada persentase saham yang dimiliki institusi, dimana semakin besar persentase saham yang dimiliki akan mendorong semakin besarnya kecenderungan perusahaan melakukan penghindaran pajak. Hal ini disebabkan karena adanya pengaruh tinggi dari pemilik saham internal perusahaan yang menginginkan nilai perusahaan yang tinggi dan keuntungan yang maksimal, sehingga mendorong terjadinya praktik penghindaran laba yang dianggap dapat menekan beban pajak perusahaan dan meningkatkan keuntungan yang akan diterima pemegang saham. Faktor kedua menurut Wijayanti, Masitoh, Mulyani (2018) yang mempengaruhi keputusan penghindaran pajak perusahaan pertambangan adalah komite audit. Hal ini disebabkan karena komite audit adalah komite yang dibentuk oleh dewan komisaris perusahaan, sehingga ada kemungkinan komite audit tersebut mendapatkan tekanan atau instruksi untuk memfasilitasi kepentingan pemegang saham perusahaan, yaitu dengan mendukung pelaksanaan penghindaran pajak oleh pengelola perusahaan. Hal ini sejalan dengan faktor yang dijelaskan dalam theory of planned behavior, yaitu perceived behavior control yang menjelaskan bahwa praktik transfer pricing akan mudah untuk dilakukan atau tidak berdasarkan pada pengalaman di masa lalu (Ajzen, 2005). Apabila tidak terdapat peluang dari komite audit, institusional, dan kualitas dari audit yang dilakukan, maka akan semakin kecil peluang perusahaan untuk melakukan transfer pricing. Hal ini juga dijelaskan oleh Wijayanti, Masitoh, Mulyani (2018) bahwa kualitas audit mampu memberikan pengaruh signifikan namun negatif terhadap keputusan penghindaran pajak oleh perusahaan. Artinya, semakin baik hasil audit yang dilakukan terhadap laporan keuangan perusahaan pertambangan akan meminimalisir terjadinya penghindaran pajak. Pelaksanaan penghindaran pajak dengan metode transfer pricing merupakan salah satu dampak dari agresivitas pajak perusahaan yang tinggi, dimana perusahaan melakukan perencanaan pajak untuk menekan beban pajak perusahaan menggunakan cara-cara yang tidak melanggar peraturan perpajakan (Hite \& McGill, 1992). Menurut temuan Dewi \& Dewi (2017), keputusan perusahaan untuk melakukan penghindaran pajak ternyata memiliki pengaruh signifikan terhadap nilai perusahaan yang diukur menggunakan proksi Tobin's $Q$ berdasarkan perspektif investasi. Artinya, semakin tinggi 
agresivitas pajak perusahaan, yang salah satunya dapat terealisasi dalam bentuk pelaksanaan transfer pricing, akan mendorong semakin meningkatnya investasi terhadap perusahaan. Hal ini mungkin disebabkan karena adanya penilaian investor bahwa perusahaan yang mampu menekan beban pajaknya semaksimal mungkin akan memberikan keuntungan yang lebih besar kepada pemegang saham perusahaan. Dewi \& Dewi (2017) juga menemukan bahwa transparansi informasi akan memperkuat pengaruh dari agresivitas pajak terhadap nilai perusahaan. Dengan demikian, keberadaan beragam media informasi dan perkembangan teknologi komunikasi yang semakin canggih akan dapat semakin mendorong pelaksanaan penghindaran pajak akibat semakin tingginya agresivitas pajak perusahaan demi mendorong peningkatan nilai perusahaan.

Secara keseluruhan dapat dipetakan beberapa faktor yang memiliki pengaruh terhadap keputusan pelaksanaan transfer pricing oleh perusahaan pertambangan, yaitu karakteristik eksekutif, leverage, skala perusahaan sebagai perusahaan multinasional, pengungkapan tanggung jawab sosial, capital intensity, kepemilikan institusional, komite audit, kualitas audit, dan transparansi informasi. Sembilan faktor tersebut dapat menyebabkan perusahaan berupaya melakukan transfer pricing demi dapat memperkecil beban pajak yang harus dibayarkan kepada negara. Pengaruh yang diberikan dapat bersifat parsial atau simultan tergantung pada situasi ekonomi dan penegakan regulasi perpajakan di Indonesia.

\section{SIMPULAN}

Berdasarkan hasil penelitian yang telah dilakukan, maka kesimpulan yang didapatkan dari penelitian ini yang pertama adalah skema transfer pricing yang dilakukan oleh perusahaan pertambangan secara umum dapat dibagi menjadi dua, yaitu dengan cara melakukan pengalihan kuasa pertambangan kepada perusahaan lain yang memiliki hubungan istimewa dan melakukan transaksi dengan perusahaan yang memiliki hubungan istimewa, seperti antara perusahaan induk dan anak cabang perusahaan yang berada di luar negeri, dengan harga yang besarnya disepakati di bawah rata-rata harga pasar. Sedangkan yang kedua adalah terdapat sembilan faktor yang mempengaruhi keputusan pelaksanaan transfer pricing oleh perusahaan pertambangan, yaitu karakteristik eksekutif, leverage, skala perusahaan sebagai perusahaan multinasional, pengungkapan tanggung jawab sosial, capital intensity, kepemilikan institusional, komite audit, kualitas audit, dan transparansi informasi.

Berdasarkan kesimpulan penelitian yang telah dijelaskan, maka saran yang dapat diajukan adalah pihak pemerintah dapat meningkatkan peran akuntan publik untuk menguji kewajaran perhitungan jumlah transaksi yang diungkapkan perusahaan dalam laporan keuangan. Selain itu, untuk mendukung proses perhitungan kewajaran, dibutuhkan harga wajar pembanding dari setiap komoditas tambang, sehingga pemerintah dapat mengupayakan untuk menyediakan data center, yang berfungsi untuk mengupdate harga terbaru setiap komoditas tambang. Saran bagi penelitian selanjutnya supaya dapat melakukan kajian lebih mendalam terhadap faktorfaktor yang mempengaruhi keputusan transfer pricing menggunakan data primer 
yang terbaru untuk menemukan gambaran praktik penghindaran pajak perusahaan pertambangan yang lebih aktual. Selain itu, skema penghindaran pajak perusahaan pertambangan yang dirumuskan dalam penelitian ini juga dapat dikaji lebih mendalam melalui studi kasus dengan mengambil objek penelitian yang lebih spesifik untuk dapat lebih melengkapi skema transfer pricing tersebut.

\section{REFERENSI}

Ajzen, I. (2005). Attitudes, Personality And Behaviour (Second). New York: Open University Press.

Anita Wijayanti, Endang Masitoh, Sri Mulyani. (2018). Pengaruh Corporate Governance Terhadap Tax Avoidance (Perusahaan Pertambangan yang terdaftar di BEI). Jurnal Riset Akuntansi Dan Bisnis Airlangga, 3(1), 322-340. https://doi.org/10.31093/jraba.v3i1.91

Astrianti, Y., \& Triyanto, D. N. (2018). Pengaruh Karakter Eksekutif , Proporsi Komisaris Independen, Dan Capital Intensity Terhadap Tax Avoidance ( Studi Kasus pada Perusahaan Pertambangan subsektor Batubara yang terdaftar di Bursa Efek Indonesia Tahun 2012-2016 ). E-Proceeding of Management, 5(3), 3429-3436.

Badan Pusat Statistik. (2018). Produk Domestik Bruto Indonesia Triwulanan 20142018. Jakarta.

Barker, J., Asare, K., \& Brickman, S. (2017). Transfer pricing as a vehicle in corporate tax avoidance. Journal of Applied Business Research, 33(1), 9-16. https://doi.org/10.19030/jabr.v33i1.9863

Biro Analisa Anggaran dan Pelaksanaan APBN. (2014). Potensi Penerimaan Pajak dengan Meminimalisir Praktek Transfer Pricing. Retrieved from http://www.dpr.go.id/doksetjen/dokumen/apbn_Potensi_Penerimaan_Pa jak_Dengan_Minimalisir_Praktek_Transfer_Pricing20140821142540.Pdf

Budileksmana, A. (2018). Manfaat Dan Peranan Konsultan Pajak Dalam Era Self Assessment Perpajakan. Jurnal Akuntansi \& Investasi, 1(2), 77-84.

Burhanudin. (2012). Theory Of Planned Behavior: Aplikasi Pada Niat Konsumen Untuk Berlangganan Surat Kabar Harian Kedaulatan Rakyat Di Desa Donotirto, Kecamatan Kretek, Kabupaten Bantul. Artikel Ilmiah Mahasiswa.

Busthomi. (2016). Perusahaan Tambang Banyak Kemplang Pajak, NGO: Pemerintah Harus Berani Tagih Piutang Pajak. Retrieved October 22, 2019, from Aktual website: https://aktual.com/perusahaan-tambang-banyakkemplang-pajak-ngo-pemerintah-harus-berani-tagih-piutang-pajak/

Dewi, A. A., \& Dewi, L. G. K. (2017). Transparasi Informasi Memoderasi Pengaruh Agresivitas Pajak Pada Nilai Perusahaan Pertambangan di Bursa Efek Indonesia. Akuntabilitas, 10(2), 211-230. https://doi.org/10.15408/akt.v10i2.6134

Dewi, N., Nasir, A., \& ' H. (2016). Pengaruh Karakter Eksekutif, Karakteristik Perusahaan, Dan Pengungkapan Tanggung Jawab Sosial Perusahaan Terhadap Penghindaran Pajak (Studi Empiris Perusahaan Pertambangan yang Terdaftar di BEI 2011-2013). Jurnal Online Mahasiswa Fakultas Ekonomi Universitas Riau, 3(1), 1006-1020.

Direktorat Sumber Daya Energi Mineral dan Pertambangan. (2019). Kajian 
Ketercapaian Target DMO Batubara Sebesar 60\% Produksi Nasional Pada Tahun 2019. Jakarta.

Hidayat, W. W. (2018). Pengaruh Profitabilitas, Leverage Dan Pertumbuhan Penjualan Terhadap Penghindaran Pajak. Jurnal Riset Manajemen Dan Bisnis (JRMB) Fakultas Ekonomi UNIAT, 3(1), 19-26. https://doi.org/10.36226/jrmb.v3i1.82

Hite, P. A., \& Mcgill, G. A. (1992). An Examination of Taxpayer Preference for Aggressive Tax Advice. National Tax Journal, 45(4), 389-403.

Hongren, T., \& Foster, G. (2008). Akuntansi Biaya dengan Penekanan Manajerial. Jakarta: Erlangga.

Kementrian Keuangan Republik Indonesia. (2018). APBN KITA: Kinerja dan Fakta. Jakarta.

Kementrian Keuangan Republik Indonesia. (2019). Asumsi Dasar Ekonomi Makro \#APBN2019. Retrieved October 22, 2019, from Kemenkeu.go.id website: https://www.kemenkeu.go.id/apbn2019

Lindblom, A., \& Lindblom, T. (2018). Applying the Extended Theory of Planned Behavior to Predict Collaborative Consumption Intentions (Vol. 11). Singapore: Springer.

Moleong, L. J. (2017). Metode Penelitian Kualitatif (30th ed.). Jakarta: Remaja Rosdakarya.

Permatasari, I., \& Laksito, H. (2013). Minimalisasi tax evasion melalui tarif pajak, teknologi dan informasi perpajakan, keadilan sistem perpajakan, dan ketepatan pengalokasian pengeluaran pemerintah. Diponegoro Journal of Accounting, 2(2), 1-10.

Pohan, C. A. (2018). Panduan Lengkap Pajak Internasional. Jakarta: Gramedia Pustaka Utama.

Putra, P. D., Syah, D. H., \& Sriwedari. (2018). Tax Avoidance Practices as a Proof of Agency Theory and Tax Planning in Indonesia Stock Exchange. International Journal of Research \& Review, 5(9).

Putri, W. A. (2017). Prinsip Kewajaran dan Dokumen sebagai Penangkal Kecurangan Transfer Pricing di Indonesia. Jurnal Riset Akuntansi Dan Keuangan, 2(2), 47-56. https:/ / doi.org/10.17509/jrak.v5i2.8029

Rachdianti, F. T. (2016). Pajak merupakan salah satu sumber penerimaan negara yang memiliki peran penting dalam menopang pembiayaan pembangunan dan menggambarkan kemandirian Pada Anggaran Pendapatan dan Belanja Negara ( APBN ) diketahui pajak merupakan salah satu komponen Penerima. Jurnal Perpajakan Universitas Brawijaya, 11(1), 1-7.

Safitri, R. H., \& Aulia, B. (2017). Optimalisasi Peran Behavioral Accounting Guna Penerapan Dalam Praktik Transfer Pricing. Seminar Nasional Akuntansi Dan Bisnis, 1038-1044.

Silalahi, U. (2018). Metode Penelitian Sosial. Bandung: PT Refika Aditama.

Spicer, M. W., \& Hero, R. E. (1985). Tax Evasion and Heuristic: A Research Note. Journal of Public Economics, 26, 263-267.

Wallschutzky, I. (1985). Taxpayer Attitudes to Tax Avoidance and Evasion. Sydney: Australian Tax Research Foundation.

Waris, A. (2013). Taxing Intra-Company Transfers: The Law and Its Application in Rwanda. Bulletin for International Taxation, 67(12), 679. 
Wibowo, W. (2011). Cara Cerdas Menulis Artikel Ilmiah. Jakarta: Penerbit Buku Kompas.

Yuliawati. (2019). Gelombang Penghindaran Pajak dalam Pusaran Batu Bara. Retrieved October 22, 2019, from Katadata.co.id website: https:/ / katadata.co.id/opini/2019/02/11/gelombang-penghindaran-pajakdalam-pusaran-batu-bara 